\title{
FROM UNIVERSAL LITERATURE CLASSICS TO SOCIAL SCIENCES: MAPPING THREE INTRANSLATION PROJECTS IN MEXICO
}

Tania Paola Hernandez-Hernandez ${ }^{\underline{1}}$

El Colegio de Mexico, Cidade do México, México

\begin{abstract}
The concept "intranslation" was coined in 1992 to refer to the importation of foreign books into a national language via translation. Since then, the concept has travelled, and its meaning has expanded to describe other aspects of the international production, circulation and reception of texts, such as the symbolic and material spaces, capitals and practices involved in these processes. With the purpose of continuing to explore its explanatory power, in this article I argue intranslation has been the dominant process in Mexico's translation policies of the $20^{\text {th }}$ century. I examine three intranslation projects supported and/or implemented by the Mexican government. The article is divided into two main sections. The first section outlines the concepts of translation policy, intranslation and extranslation. The second section begins with an overview of the evolution of the Mexican publishing field. This is followed by a description of three translation projects supported by the Mexican government and by the analysis of the evolution of the roles and values attributed to translation. Keywords: Translation Policy; Sociology of Translation; Intranslation; Extranslation; Mexican Publishing Field
\end{abstract}

\section{DOS CLÁSSICOS DA LITERATURA UNIVERSAL ÀS CIÊNCIAS SOCIAIS: MAPEANDO TRÊS PROJETOS DE INTRADUÇÃO NO MÉXICO}

Resumo: O conceito de "intradução" foi cunhado em 1992 para se referir à importação de livros estrangeiros para uma língua nacional através da tradução. Desde então o conceito tem viajado e seu significado foi 
expandido para descrever outros aspectos da produção internacional, da circulação e recepção de textos, como os espaços material e simbólico, os capitais e as práticas envolvidas nesses processos. Com o objetivo de continuar investigando seu poder explanatório, eu discuto nesse artigo que a intradução foi um processo dominante nas políticas de tradução do México no século 20. Eu examino três projetos de intradução financiados e/ou implementados pelo governo mexicano. O artigo é dividido em duas seções principais. A primeira seção discorre sobre os conceitos de política de tradução, intradução e extradução. A segunda seção começa com uma visão geral da evolução do campo editorial mexicano. Esta é sucedida pela descrição de três projetos de tradução financiados pelo governo mexicano e pela análise da evolução dos papéis e valores atribuídos à tradução.

Palavras-chave: Política de Tradução; Sociologia da Tradução; Intradução; Extradução; Campo Editorial Mexicano

\section{Introduction}

The international circulation of translated books is a system organised in a core-periphery structure (Heilbron 12), ${ }^{1}$ where the languages that are translated the most occupy the core, and those that translate more than they are translated are located in the periphery. ${ }^{2}$ This model offers a clear-cut representation of the translated books flows. However, as illustrated by the work of, for example, Pascale Casanova, Gisèle Sapiro, ${ }^{3}$ and Gustavo Sorà, the international

1 Casanova ((b) 287) explains that such structure does not fully reflect the asymmetric power relations of this system; instead, she advocates for the use of the paired concepts of dominant-dominated.

${ }^{2}$ Hence, while English occupies a hyper-central position -as about 80 percent of translations are from English come from English -, languages such as French, German and Russian occupy a central position -as they represent 10 to 12 percent of translations (Heilbron 14). Languages such as Spanish, Italian, Danish, Swedish, Polish and Czech are located in the semi-periphery, as they only account for "between 1 and 3 percent of the total number of translated books" (Heilbron 14). Although these figures are not exact and most of them need to be updated, they give us a general idea of the major trends within the international translation system.

3 Casanova and Sapiro have explained, that, in addition to the languages significance, the position of publishing fields which, up until relatively recent,

Cad. Trad., Florianópolis, v. 40, n⿳0 2, p. 77-97, mai-ago, 2020. 
circulation of this cultural goods has relied, to a significant extent, on the support of national or international institutions. The implementation of translation policies and, in some cases, of institutions and agents responsible of applying such policies has been a key factor for the importation and exportation of books via translation. In this article, I argue that the position occupied by the cultural and the publishing fields of a given national space in the international translation system influences whether a translation policy will favour the importation or the exportation of texts via translation. To illustrate this, I examine three translation projects that have been implemented and supported by the Mexican government in the $20^{\text {th }}$ century: two via the Ministry of Public Education and one via the partial funding of a publishing house. These projects were mostly aimed at translating foreign literature and social science books in Mexico; in the long term, they were aimed at supporting the development of the cultural and the university Mexican fields. The first project, called the "Clásicos [classics]" (1921-1924) led and funded by the Ministry of Public Education, consisted on the massive printing of a selection of classical texts of authors like Homer, Shakespeare, Dante, Miguel de Cervantes, Plato, Tolstoy, Ibsen and Goethe. The second project consisted in the partial economic funding of Fondo de Cultura Económica (henceforth referred as FCE, Fondo), a publishing house originally created to translate and disseminate texts on economy theories among undergraduate students. Published during the 1970s and the early 1980s, the book series "SepSetentas" [SepSeventies] is the third project analysed in this article. Launched and supported by the Ministry of Public Education, this massive-printing project led to the publication of 315 books, 42 of which were translations mainly from English and French.

The rationale for addressing these projects is threefold. Firstly, Mexico's publishing field occupied (and still does) a semi-central

still coincided with the borders of the national states, also influences the intensity of translation flows and, more importantly for the argument of this article, the direction of such flows.

Cad. Trad., Florianópolis, v. 40, n⿳0 2, p. 77-97, mai-ago, 2020. 
position in the Spanish publishing field. Secondly, these projects emerged at crucial times of the development of the Mexican publishing field, thus they enable the observation of the evolution of the role and values attached to translation and translated books in this field. Thirdly, they shed light on the products and interplay at stake in the translation policies of the agents of the Mexican political, literary and scientific fields. ${ }^{4}$ I draw on the notions of intranslation, extranslation and translation policy to study the evolution of the role assigned to translation by agents of the political and cultural fields of Mexico. These notions are defined in the next section.

\section{Intranslation as translation policy}

For both literary and scientific books, translation has been "the primary vehicle for the international circulation of books since the second half of the $19^{\text {th }}$ century" (Sapiro (a) 7). According to Gabriel González Núñez, in addition to technological improvements and the professionalisation of publishing practices, the support of translated books flows has relied heavily on development of translation polices that involve translation decisions, practices, and beliefs. Developed and applied by public authorities, international organisations and/or individual agents, the configuration of these policies and the direction of translation flows are shaped by the languages positions in the international linguistic market and the international publishing space.

The transfer of translated books is thus embedded in a set of asymmetric power relations of economic, politic, and cultural nature. These three factors play a key role in the configuration

\footnotetext{
${ }^{4}$ The functioning of the Mexican case has specificities that distinguish it from other relevant fields in the Latin American publishing landscape. For example, while the government has played a crucial role in the implementation and development of translation projects via the creation of specific publishing institutions, the Argentinean publishing field has evolved independently from the political sphere (De Diego 2014).
}

Cad. Trad., Florianópolis, v. 40, nº 2, p. 77-97, mai-ago, 2020. 
of the international and national publishing fields; thereby, in the direction and intensity of translation processes. ${ }^{5}$ Coined by Valérie Ganne and Marc Minon, the concepts of "intranslation" and "extranslation" represent precisely the movements of translated literary books from and into Metropolitan French and the French literary field. Hence, while intranslation describes the importation of foreign texts into specific national language and publishing spaces; ex-translation refers to the exportation of texts and their translation "into one or more foreign languages" (Ganne \& Minon 58) and their introduction into foreign literary and publishing spaces. ${ }^{6}$ This means that while extranslation is the main process of book transfer in the countries that occupy a central position, intranslation is more frequent in those countries that are located in the periphery. Ganne and Minon also argue that governmental support is key particularly in the case of those literatures that only spread within a very limited small linguistic area, such as Swedish, Dutch and Czech. ${ }^{7}$

${ }^{5}$ For example, Zorina González Khan explains that protectionist laws were instrumental for the consolidation of the U.S. publishing industry in the $19^{\text {th }}$ century. In a few words, the U.S. copyright laws did not offer any protection to foreign writers until the 1891; hence, American publishers translated and reprinted both translations and books originally written in English without paying any royalties to original authors, translators or publishers. Likewise, Sapiro ((b) 34) suggests that something similar could be said in the case of other cultural capitals like Leipzig, Paris and London.

${ }^{6}$ Jurt has used these concepts to look at the importation and exportation of translated books between French and Germany during the 1990s.

${ }^{7}$ In the data presented by Ganne and Minon, the participation of governmental institutions comes to the fore. In the case of France, for example, the Centre National du Livre [National Book Center] (henceforth CNL) has played a salient role in the intranslation of literature in the French literary field. The programme "Aides aux éditeurs pour la traduction [Aid to publishers for translation]" was created during the mid-1980s to support the intranslation of literary and scientific texts into Metropolitan French and the extranslation of French literature in other languages (Buzelin). In 1990 the CNL founded the translation of 209 texts; by 2012 , the CNL funds in average 330 translation projects every year, from which around 60 percent is allocated to intranslation projects. Other countries have 
On the other hand, Casanova ((b) 360) refers to intranslation and extranslation to explain how the position of a given literature or language in the international literary field shapes the role of translation as either a consecrating function or an accumulation strategy. For those literatures that occupy a dominated position in the international literary field -which, mutatis mutandis, in Heilbron's model (12-14) would be located at the periphery translation of literary canonical texts would function as a strategy to accumulate prestige. Conversely, translation functions as a consecrating strategy when the literatures considered as dominant translate a text or an author from a dominated literary field. Thus intranslation and extranslation projects can be implemented as a translation policy for positioning given languages as well as literary and scientific fields. The three cases examined in the next section illustrate precisely how translation was mainly aimed at accumulating and appropriating literary and scientific resources.

Although Spanish is spoken by the vast majority of the inhabitants of Latin America, a poor communication and transport systems, as well as local policies and idiosyncrasies, have long hindered cultural and economic exchanges. The distribution and circulation of cultural works have also been affected by these circumstances. To deal with these difficulties the publishing industries and the individuals therein involved have resorted to a manifold of mechanisms that, in the long term, led to the creation of an import-export network, that included associating with local sellers, printers, peddlers, and other agents. ${ }^{8}$ In the late

created similar institutions and programmes to promote their publishing output.

${ }^{8}$ In her study of the British Book trade in the Hispanic Americas, Eugenia Roldán Vera explains that transport and communication infrastructure in the Spanish American countries was underdeveloped during the Spanish rule. The transport and distribution costs were, by large, assumed by the merchants themselves. Consequently, "foreign merchant houses only cared for the transportation and distribution of goods in the main cities" (2003), leaving to peddlers the distribution of said goods in smaller cities and villages. For what regards to printing materials, Roldán Vera argues that foreign publishing houses relied on the circulation network of periodicals: "readers could subscribe to Ackermann's magazines in 
$19^{\text {th }}$ and early $20^{\text {th }}$ century, this complex structure was gradually replaced by publishing projects and companies launched by the cultural and political elites. ${ }^{9}$ In the following section, I describe the emergence of book production practices and examine the elements that influenced the setting of intranslation projects as a policy to develop the publishing and cultural Mexican fields.

\section{Intranslation projects in Mexico}

The end of the Spanish empire in America in the 1820s quickly turned the region into a blossoming market. Europeans countries were eager to recognise and profit from the independence of the new nations, particularly because, up to then, Spain had kept the circulation of material and cultural goods under a strict control (Fernández; Larraz; Roldán Vera). Nonetheless, social and political instability hindered the consolidation of social and commercial practices. Throughout the $19^{\text {th }}$ Century, the Mexican publishing space remained underdeveloped and it relied heavily on the European publishing industry for both scientific and literary texts. By the onset of the $20^{\text {th }}$ Century, a few local publishing houses and projects emerged in the Mexican capital: Botas (1920), founded by the Mexican printer, Andrés Botas; Robredo, established by the Spanish bookseller, Pedro Robredo (1919); Cvltvra (1916), launched by the Mexican writers Julio Torri and Agustín Loera; and Porrúa (1910), created by three Spanish brothers. However, as almost 83 percent of the population were illiterate (Robles Bárcena et al.; Garciadiego) authors and publishers struggled to find readers. The Ministry of Instruction was created in $1905 .{ }^{10}$ The

the provincial cities of Puebla, Zacatecas, Guadalajara and Guanajuato, possibly through the distributors of the newspaper El Sol" (117).

${ }^{9}$ In 1921, texts books from the National Preparatory School were still of French manufacture (Krauze 24). The local production was also dependent of the Spanish industry and most Mexican authors printed their books in Spain.

${ }^{10}$ This brief period of relative growth was somehow interrupted by the eruption

Cad. Trad., Florianópolis, v. 40, n⿳0 2, p. 77-97, mai-ago, 2020. 
first minister of public education was the Mexican intellectual José Vasconcelos, with him, Mexico's popular culture and education will experience a significant expansion: he founded schools in rural areas, supported the work of Mexican and foreign painters and artists, edited pedagogic periodicals such as El Maestro and La Antorcha; and, more importantly for the purposes of this article, he published the first popular series of universal literary classics. This series was part of an ambitious publishing project that was aimed at catering the literary and recreational needs of "children, young adults and adults, [...] mean and women, peasants, factory workers and middle-class readers" (Garciadiego 42). In the following section, I describe the characteristics as well as some of the implications of Vasconcelos' project to introduce translated literature in Mexico.

\subsection{The 'verdes': Intranslation as accumulation of literary capital}

Conceived and launched by Vasconcelos, the "Clásicos", also known as the "verdes" [greens] or the "pericos" [parrots] because of the green fabric that covered their pages, are considered as one of the large-scale efforts of the Mexican government to nationalise and democratise book production and, with it, make culture and education accessible to most Mexicans. ${ }^{11}$ In the "Preliminary remarks" of the

of the revolutionary struggles in 1910 (Castro, Hernández-Hernández \& Zaslavsky). The armed violence extended to at least 1920. This was followed by two decades of "institutional reform" (Knight 2016: 4), and a long-period of social and political stability. This was achieved mainly via the emergence and consolidation of an official party, whose members shared the perception that education was of paramount importance for the unification and development of the Mexican society. For the Mexican historian Javier Garciadiego, the weakness of the Mexican education system is evinced by the fact that by the end of the $19^{\text {th }}$ Century, the creation of a Ministry devoted to "educational affairs" had not been properly addressed (13).

11 The editorial impetus of Vasconcelos also materialised in other more projects: Lecturas clásicas para niños [classic readings for children] presented by Vasconcelos 
first volume, Vasconcelos regretted that "the scarcity, as well as the deficiency of Castilian editions of the most important books of the world, had forced educated people to put a lot of effort into studying foreign languages", and such conditions had also excluded "the majority of the population from reading great books" (Vasconcelos 5). Therefore, the publication of books in Spanish was perceived as both a cultural and a national need. The number of copies that were printed of each book varied between 38940 (La Iliada [The Iliad]) and 6300 (La Divina Comedia [The Divine Comedy]. The books were sold at a very accessible price $(\$ 1 \mathrm{MXN})$ and they were freely distributed to schools and libraries (Loyo).

At the time, there were only a few Mexican publishing houses. France and Spain were the editorial centres for the Hispanic market, "even New York was more important for what regards to book production in Spanish than Mexico" (Vargas 1) ${ }^{12}$. Even the efforts aimed at constituting a national culture relied heavily on foreign cultural products. This dependence can be observed in the titles that were included in Vasconcelos's collection, The Iliad, The Odyssey, Aeschylus's Tragedies, Divine Comedy, Plato's Dialogues; in total, the collection consisted of 26 titles, half of them were translations. The other selected titles were: Plato's Diálogos [Dialogues] (3 volumes), Romain Rolland's Vidas ejemplares. Beethoven, Miguel Angel. Tolstoi [Exemplary lives, Beethoven, Michelangelo, Tolstoy], Goethe's Fausto [Faust], Euripides's Tragedias [Tragedies], Aeschylus Tragedias [Tragedies], Plutarch's Vidas paralelas [Parallel Lives], Tagore's

and by Bernardo J. Gastéñum, at the time sub-minister of public education; and Lecturas para mujeres, compiled by the Chilean Nobel Gabriela Mistral. These volumes are composed by prose and poetic fragments of texts originally written in Spanish (Dr. G. Juarros, Mistral, María Enriqueta) as well as in other languages, such as English (John Ruskin, Tagore, Whitman), French (Charles Louis Phillippi, Francis Jammes, Albert Samain) and Hebrew (Salomon), to mention but a few.

12 The book culture-circuit was restricted to a very narrow elite, either because they had not been translated to Spanish, thus they were only read by those having the appropriate linguistic capitals; or because the books were unaffordable for the majority of the population (Hernández-Hernández). 
La nueva luna. Nacionalismo [The new moon. Nationalism], Agustín Rivera's Principios Críticos sobre el Virreinato de la Nueva España [Critical Principles on the Viceroyalty of the New Spain]. However, most of the translations were reprints of translations previously published in Spain (González Kahn) or indirect translations based on "authorised English and French versions" (González Kahn 161). It seems like Plotinus' Las Enéadas [Enneads] (1923), translated by Daniel Cosío Villegas from MarieNicolas Bouillet's version, was the only title that was translated for the series. Reprinting previously published translations allowed Vasconcelos to save money and time, however, by resorting to this strategy the Ministry of education also compromised the degree of appropriation of the universal classics.

The titles included in the series hints at the cultural horizon of Vasconcelos and of the other individuals involved in the project.$^{13}$ In this regard, it is noticeable that the culture to be democratised and nationalised mostly had a literary nature and a foreign origin. Nowadays, Vasconcelos's endeavour to offer "good reading options" (Vargas 17) at affordable prices is considered under a double light. On the one hand, it is remembered as the beginning of the democratisation of the access to literary culture; on the other, it is also considered as an evidence of the Mexican government's lack of planning and its proclivity to the squandering of public resources (Zaid), evinced in the massive print-runs of titles that were done without taking into account of the readers' needs, interests and sociocultural and linguistic backgrounds. ${ }^{14}$ In any case, within

13 Vasconcelos belonged to Mexican Youth Athenaeum, a civil association supported by the Ministry of Public Education, that was aimed at promoting cultural and artistic events, they were significantly "influenced by Nietzsche, Bergson and were admirers of Classic Greek philosophy and literature [...] and of the Spanish Gold Age and Pérez Galdós” (González Kahn 143).

${ }^{14}$ In addition to the projects studied in this article, the Mexican government has funded other massive print-run projects such as that of primary school textbooks, which, currently, involves the publishing of more than 200 million copies (Arista, Bonilla \& Lima) in 42 languages every year.

Cad. Trad., Florianópolis, v. 40, no 2, p. 77-97, mai-ago, 2020. 
Vasconcelos project, translation is aimed at "'nationalizing' literature's "great universal texts" (Casanova (b) 291). This appropriation is not only achieved by translating said texts into Mexico's national language but also by making the translated texts affordable and accessible to most of the population. Unfortunately, there was not an effective distribution and sales strategies, and fifteen years later, the "Clássicos" had not sold out (Zaid).

\subsection{Fondo de Cultura Económica: Intranslation as accumu- lation of academic capital}

In 1934, the Fondo de Cultura Económica [hereafeter referred as Fondo], Mexico's most iconic and active publishing house for what regards to the intranslation of Social Sciences and Humanities into Spanish, was founded by Daniel Cosío Villegas, a former contributor of Vasconcelos's project. For Cosío Villegas, the foundation of the Fondo as essential for the consolidation of the Mexican cultural and scientific fields, as such, it benefited from the government's economic support. Over the years, this support has been used to influence the managing and destiny of the publishing house. ${ }^{15}$ In 1935, the Fondo officially started its operations with the translation of scientific articles and a few books on Economics such as William Shea's El dólar plata [Silver dollars] (1935, c1935), and Harold Laski's Karl Marx (1935, c1922). Despite the need for academic texts by Mexican university students of economy and Cosío Villegas' personal investment, the lack of economic resources slowed down the translation and printing of books during the early years of the Fondo. By the end of the 1940s, the Fondo

\footnotetext{
${ }^{15}$ One of the most public cases of the government's pressure on the Fondo occurred in 1964 when, Arnaldo Orfila Reynal, at the time director of the Fondo, was fired after translation and publishing Los hijos de Sánchez [The Children of Sanchez]. Originally written in English by the American anthropologist Oscar Lewis, Los hijos de Sánchez offered a dramatic and raw portrayal of a Mexican family living in poverty, as such, it was considered as an uncomfortable (Garciadiego) text by the Mexican ruling elite.
} 
had translated and published sixteen titles that were organised in four series: Economía [Economics] (1935), Política y Derecho [Politics and Law] (1937), Sociología [Sociology] (1939) e Historia [History] (1939). This situation changed significantly with the arrival of the Spanish Republican intellectuals, philosophers, writers, who were forced to leave Spain after the victory of the Fascists Nationalists.

With the purpose of consolidating the new state, its material expansion and transformation (Lida 86-88), the Mexican government supported the immigration of those Spanish exiles that could contribute to boost the economy. The newcomers joined and boosted Mexico's scientific and cultural arenas. Their contribution to the publishing field and, in particular, to the intranslation of social sciences and humanities is remarkable, "in just eleven years, the exiles participated in the edition of 2250 titles, scientific, literary and philosophy books; [...] and they did over 1600 translations in two decades" (Guevara 1991: 176). ${ }^{16}$ For what regards to the Americas indigenous heritage, only two volumes were published: Popol Vuh (1947) and Memorial de Solola (Memorial de Tecpan-Atitlan) Anales de los Cakchiqueles. [Memorial of Sololá (Memorial de Tecpán-Atitlán) Annals of the Cakchiquels] (1950), translated from Kaqchikel into Spanish by the Guatemalan historian Adrián Recinos.

By 1955, 75 percent of the 697 titles published by the Fondo were translations. In any case, the editorial policy governing the title selection and publication of the Fondo can be described as "rich, open, critic, varied, pedagogical, elastic,

\footnotetext{
${ }^{16}$ Initially, "Biblioteca Americana" was a series created "to resurface the best works written by Hispanic-speakers from all countries and periods" (CosíoVillegas 1). However, with the aim of offering a more comprehensive picture of the complex and mixed intellectual heritage of the Americas, the directors of the collection have included a few texts originally written in English and Portuguese, such as Machado de Assis' Memorias póstumas de Blas Cubas (1951) and, more recently, Hans Friedrich Gadow's Viajes de un naturalista por el sur de México, which originally was written and published in English (1908), and translated in Spanish by Teresa Moreno and published in 2011.
}

Cad. Trad., Florianópolis, v. 40, no 2, p. 77-97, mai-ago, 2020. 
balanced, inclusive, liberal" and, definitively "Eurocentric" and "Anglophile" (Krauze 26,29). The new books covered different subjects. This lead to the creation of five more series: Ciencia y Tecnología [Science and Technology] (1945), Antropología [Anthropology] (1944), Biblioteca Americana [American Library] (1947), Breviarios [Breviaries] (1948), Tierra Firme [Firm Land] (1944), and Tezontle (1938). All the collections included translated titles. Other publishing companies, both national and foreign, private and public, followed the steps of the Fondo and gradually populated Mexico's publishing field. By 1959 (Mantecón), according to the only registered index of the translated titles published in Mexico, ${ }^{17} 544$ books were intranslated to Mexico, 112 (21 percent) were Social Sciences and Humanities books, 67 percent of which were translated from English. And, although there were at least 70 active publishing houses in Mexico, the majority of these books were translated and published by the FCE, UNAM, Editorial Novaro-México and Editora Nacional (Hernández-Hernández forthcoming).

Translation plays a more diverse role in this second intranslation project because it does not only function as a practice to accumulate literary and scientific capitals, but it also contributes to the integration of the Spanish exiles in the Mexican social field, particularly in the cultural and publishing ones. ${ }^{18}$ In any case, the welcoming policies of the Mexican government towards the Spanish exiles as well as the economic support given to FCE were vital for the progressive positioning of Fondo de Cultura as a translation and publishing agent in the Hispanic American publishing market.

\footnotetext{
${ }^{17}$ Subsequent attempts to compile and register intranslation figures only offer a partial, unsystematic account of the impact of this process (Hernández-Hernández forthcoming).

${ }^{18}$ It is worthwhile to mention that, at least for what regards to the Mexican publishing field, translation is not a very frequent practice between the Mexican population and it is still carried out by non-national Spanish speakers.
} 


\subsection{SepSetentas: A mixed intranslation project}

Between the 1930s and the 1960s, ${ }^{19}$ the government's efforts to support culture through the massive publication of books materialised in the production of various fiction series..$^{20}$ However, the Ministry reduced its participation in the publishing field to "enable the healthy competition" (Loyo 324) within this field. ${ }^{21}$ Although the collection was named "SepSetentas" after the decade in which it was launched, the publication of this collection spans from 1971 to $1982 .{ }^{22}$ The collection was run by Gonzalo Aguirre Beltrán, at the time assistant minister of Popular Culture and Extracurricular Education of the Mexican Ministry of Public Education.

Like the titles of "Clásicos", the books of "SepSetentas" were mass produced in print runs of 10,000 to 30,000 copies (Martínez 31 ), and they were also distributed for free within the libraries and other dependencies of the educational system. However, there are some significant differences. The presence of translated titles

${ }^{19}$ The 1960s had been outstanding for the literary intranslation of Latin American writers. For example, before that period only 146 Latin American titles had been published in the United States; fifteen years later there were 414 (Mudrovcic 133).

${ }^{20}$ Some of these series were "Cuadernos de Lectura Popular [Popular reading notebooks]" (1960s), "Para decir, contar, cantar [To say, tell, sing]" (1980s), "El Correo del Libro [The book mail]" and "Lecturas Mexicanas [Mexican readings]", a series coedited with FCE (Cervantes 287).

${ }^{21}$ It is worth mentioning that before the creation of the National Commission for Free Textbooks in 1959, the textbooks used at Mexican primary schools were from "foreign authors" or "translated from foreign languages", and sometimes they "reflected the profit-oriented philosophy of their authors and publishers" (Neumann \& Cunningham 23). The dependence of foreign content could also be confirmed in the institutional magazine of the SEP Coopera which was aimed at establishing a dialogue between educational authorities and the general public, as well as to assist school teachers. In spite of the "national character of the Ministry [of Public Education]" (Loyo 317) the magazine at least a third of its content was composed of translations of articles and texts written by foreign pedagogues, psychologists or physicians.

${ }^{22}$ However, most of the titles, 315 out of 324, were published between 1971 and 1976.

Cad. Trad., Florianópolis, v. 40, nº 2, p. 77-97, mai-ago, 2020. 
was significantly reduced as most of the 324 titles included in SepSetentas were originally written in Spanish and only 9 (less than 3 percent) were translated into Spanish, from English (3), French (5), and German (1). ${ }^{23}$ A shift in the perception of what was necessary for the national culture has also taken place; and, instead of classical literature, the topics of the new collection were dedicated to history, sociology, economy, geography, urbanism, pedagogy and science. The books were essentially addressed to an audience having an intermediate level of education, however, some of the history and anthropology books were the product of specialised investigations, such as Doctoral and Master theses (Velázquez 383). Hence, despite the translation of some titles and the unevenness of the "value" and "usefulness" of the collection (Velázquez 389), SepSetentas evidences and effort to support and disseminate, in a rather massive and affordable manner, the knowledge produced in Mexico.

Similar to Fondo, this last, intranslation effort also indicates a more comprehensive and diverse understanding of the cultural and intellectual products that should be available for the Mexican readership; and, like the series produced by Fondo de Cultura, the series of SepSetentas offers a combination of translated texts and of texts originally written in Spanish mostly by Mexican historians and anthropologists. Nonetheless there are some significant differences. First, unlike the translations of Fondo de Cultura, those of SepSetentas are carried out by Mexican translators or by second generation Spanish exiles, and the books are addressed to a larger audience than those of Fondo de Cultura. In this last intranslation project, translation continues to contribute to the accumulation of literary and scientific capitals.

${ }^{23}$ See Velázquez for a detailed description of the titles included in SepSetentas.

Cad. Trad., Florianópolis, v. 40, no 2, p. 77-97, mai-ago, 2020. 


\section{Concluding remarks}

The international and national publishing fields are mediated and shaped by a complex circuit of translators, publishers, editors, and other economic and political actors, who "decide what is 'in' and what is 'out' of the marketplace of ideas" (Coser 14) and cultural products. In the case of Mexico, the emergence and consolidation of more inclusive and homogenous networks of culture and knowledge consumption went hand in hand with the adoption of intranslation as an editorial practice and a translation policy. The three cases studied in this article also illustrate the importance of the government support for the implementation of said policy. These cases also outline the evolution of this policy during the $20^{\text {th }}$ century and how, as the Mexican publishing field consolidated, intranslation was replaced by other policies more directed to support the production and dissemination of local knowledge and literature.

Over the years, other collections, other publishing houses, other actors, and other translation and publishing practices, as well as other perceptions of central languages have emerged within the Spanish-speaking arena. In Mexico, for example, the government's support to intranslation has been replaced by an emphasis on the need to learn English and on the importance of producing national knowledge directly in that language, to thus enable its circulation in the international space. This shift has been enabled by the increasing communication and mobility amongst both national and foreign academic, cultural, and political actors. It is worth mentioning that it has also preceded and eclipsed the government's policies to tackle the challenges posed by Mexico's multicultural and multilinguistic composition.

On the other hand, the internationalisation of the publishing field has enabled the establishment of book circulation networks even in poor countries or regions that are symbolically, materially, geographically and/or linguistically distant from the centres of knowledge and cultural production and distribution. Said networks 
mostly operate in one direction. This means that intranslation is the dominant process for those nations that do not occupy a central position in the knowledge network. Extranslation, on the other hand, is the privileged one for those that are at the centre. From the perspective of the role of intranslation processes in the growth and maturing of cultural and scientific spaces, one of the crucial aspects that would require further research is the influence of those cultural and intellectual goods on the local cultural and knowledge production.

\section{References}

Arista, V.; Bonilla, F.; Lima, L. "Los libros de texto y la enseñanza de la Historia en México”, Proyecto Clío 36. 2010. Available at: http://clio.rediris.es. Access in: 12 November 2019.

Buzelin, H. "Traduire pour le Centre national du livre". COnTEXTES [Online], Varia, 2015. Available at: http://journals.openedition.org/contextes/6095. Access in: 12 November 2019.

Casanova, P (a). The World Republic of Letters. Trans. by M. B. de Bevoise. Cambridge, Mass.: Harvard University Press, 2004.

Casanova, P (b). "Consecration and Accumulation of Literary Capital: Translation as Unequal Exchange”. Trans. by S. Brownlie. In: M. Baker (Ed.). Critical readings in Translation Studies. London \& New York: Routledge, 2010, p. 285-303.

Castro, N.; Hernández, T.; Zaslavsky, D. "Los traductores y los libros del México del siglo $\mathrm{XX}$ : una mirada retrospectiva y un balance pendiente. In: Garone, M.; Bello, K. La historia del libro mexicano. Siglo XX. Mexico City: UAM-Cuajimalpa, forthcoming. 
Cervantes, F. "Colecciones y formación de gustos literarios en México". Andamios, v. 6, n. 12, (2009): 279-298. Available at: https://goo.gl/YaLbYf. Access in: 12 November 2019.

Coser, L. "Publishers as Gatekeepers of Ideas". The Annals of the American Academy of Political and Social Science, v. 421, (1972): 14-22.

Cosío, D. Carta a Pedro Henríquez Ureña. 18 December. Mexico City: Historic Archive of Fondo de Cultura Económica, 1945.

De Diego, J. L. (Dir.). Editores y políticas editoriales en Argentina (1880-2010). Buenos Aires: FCE, 2014.

Fernández, P., "El monopolio del mercado internacional de impresos en castellano en el siglo XIX: Francia, España y la "ruta" de Hispanoamérica". Bulletin hispanique, v. 100, n.1, (1998): 165-190.

Ganne, V. ; Minon, M. "Géographies de la traduction". In: Barret-Ducrocq, F. (Dir.). Traduire l'Europe. Paris: Payot, 1992, p. 55-95.

Garciadiego, J. Autores, editores, instituciones y libros: Estudios de historia intelectual. Mexico City: FCE, 2015.

González Kahn, O. "Los clásicos de Vasconcelos y sus traducciones”. In: Castro, N. (Coord.). Traducción, identidad y nacionalismo en Latinoamérica. Ciudad de México: Bonilla Artigas Editores-CONACULTA-FONCA, 2014 p. 141-172.

González Núñez, G. “On Translation Policy”. Target, v. 28, n. 1, (2016): 87109.

Guevara, G. "La cultura mexicana y el exilio español". In: AA. VV. Cincuenta años de exilio español en México. Tlaxcala: University, 1991. p. 173-182.

Hernández-Hernández, T. “Geografías de la 'intraducción': una mirada a la circulación de textos traducidos en México a través del Índice de las traducciones impresas en México, 1959”. In: Garone, M. (Ed.) Orden y desorden de la cultura escrita. Mexico City: UNAM, Forthcoming. 
Heilbron, J. "The social sciences as an emerging global field”. Current sociology, v. 62 , n. 5, (2014): 685-703.

Heilbron, J. "Translation as a cultural world system". Perspectives: Studies in Translatology, v. 8, n. 1, (2000): 9-26.

Jurt, J. "L'intraduction de la littérature française en Allemagne". Actes de la Recherche en Sciences Sociales. v. 130, (1999): 86-89.

Knight, A. The Mexican Revolution: A Very short introduction. Oxford: University Press, 2016.

Krauze, E. Libro conmemorativo del primer medio siglo. Fondo de Cultura Económica. Mexico City: FCE, 1984.

Larraz, F. Una historia trasatlántica del libro. Relaciones editoriales entre España y América Latina, Gijón: TREA, 2010.

Lida, C. "Dos exilios: españoles y argentinos en México en el siglo XX". Filología, v.XXXIV-XXXV, (2002): 83-93.

Loyo, E. "Lectura para el pueblo". Historia Mexicana, v. 33, n. 3, (1984): 298-345.

Mantecón, J. Índice de las traducciones impresas en México, 1959. Mexico City: UNAM, 1964.

Martínez, E. La política cultural de México. Paris: UNESCO, 1977.

Mudrovcic, M. "Reading Latin American Literature Abroad: Agency and Canon Formation in the Sixties and Seventies". In: Balderston, D.; Schwartz, M. (Eds.). Voice-Overs: Translation and Latin American Culture. New York: State University Press, 2002. p. 129-143.

Neuman, P.; Cunningham, M. Mexico's Free Textbooks. Nationalism and the Urgency to Educate. Washington: The World Bank, 1982. 
Robles Bárcena, M.; et al. "El analfabetismo". In: Narro Robles, J.; Martuscelli. J.; Quintana y Barzana García, E. (Coords.). Plan educativo nacional. Mexico City: Dirección General de Publicaciones y Fomento Editorial, UNAM, 2012. Available at: http://www.planeducativonacional.unam.mx. Access in: 12 November 2019.

Roldán Vera, E. "Libros extranjeros en Hispanoamérica independiente: de la distribución a la lectura". In: Gutiérrez, M. (Coord.). Impresos y libros en la historia económica en México (siglos XVI-XIX). Guadalajara: Universidad, 2007. p. 187-214.

Roldán Vera, E. The British book trade and Spanish American independence: Education and knowledge transmission in transcontinental perspective. London \& New York: Routledge, 2003.

Sapiro, G. (Dir.). Translatio: Le marché de la traduction en France à l'heure de la globalisation. Paris: CNRS Éditions, 2008.

Sapiro, G. (Dir.). Traduire la littérature et les sciences humaines. Conditions et obstacles. Paris: Ministère de la Culture et de la Communication, 2012.

Sapiro, G. "Introduction”. Bibliodiversity., v. 3, (2014a): 7-8.

Sapiro, G. "Translation as a weapon in the struggle against cultural hegemony in the era of globalisation". Bibliodiversity. v. 3, (2014b): 33-42.

Sorá, G. Traducir el Brasil. Una antropología de la circulación internacional de ideas. Buenos Aires: Zorzal, 2003.

Vaconcelos, J. "Nota preliminar". In: Homero. La Iliada. t. 1, Mexico City: Universidad Nacional de México. 5-9.

Vargas, R. "El relámpago verde de los loros". Gaceta del Fondo de Cultura Económica. v. 494, February, (2012): 16-17, 19.

Velázquez, M. "Bibliographical Essay: The Collection SepSetentas". The Americas, v. 35, n. 3, (1979): 373-389. 
Zaid, G. "Tirar millones". Letras Libres, v. 163, 2012. Available at: https:// www.letraslibres.com/mexico/tirar-millones. Access in: 12 November 2019.

Recebido em: 12/12/2019

Aceito em: 15/03/2020

Publicado em maio de 2020

Tania Paola Hernandez-Hernandez. E-mail: tphernandez@colmex.mx. ORCID: https://orcid.org/0000-0003-2549-5479 